\title{
ZARZĄDZANIE PERSONELEM W ORGANIZACJACH POZARZĄDOWYCH Z POLSKI POLUDNIOWO-WSCHODNIEJ
}

\author{
Artykuł poświęcono problematyce zarządzania personelem w organizacjach \\ pozarządowych (NGOs). W pierwszej części przedstawiono specyfikę kapitału ludzkiego \\ w organizacjach pozarządowych. Następnie przedstawiono wyniki badań dotyczących \\ decyzji kadrowych w NGOs z Polski południowo-wschodniej.
}

\section{WPROWADZENIE}

W gospodarce rynkowej można wyróżnić trzy obszary działalności. Sektor prywatny, który tworzą przedsiębiorstwa, sektor publiczny, który stanowią instytucje administracji publicznej, a na styku pierwszego i drugiego sektora działają organizacje pozarządowe (NGOs, non-governmental organizations). Polska „Ustawa z 24 kwietnia 2003 roku o działalności pożytku publicznego i o wolontariacie" z późn. zm. definiuje organizacje pozarządowe jako „niebędące jednostkami sektora finansów publicznych [...] i niedziałające w celu osiagnnięcia zysku, osoby prawne lub jednostki nieposiadające osobowości prawnej utworzone na podstawie przepisów ustaw, w tym fundacje i stowarzyszenia"2. W 2010 r. w Polsce zarejestrowanych było 12 tys. fundacji i 71 tys. stowarzyszeń ${ }^{3}$. W związku z dużą liczbą organizacji pozarządowych, a tym samym dużą konkurencyjnością w trzecim sektorze NGOs poszukują efektywnych możliwości w zarządzaniu. Dlatego też aspekt zarządzania zasobami ludzkimi odgrywa ważną rolę w organizacjach trzeciego sektora. W tworzeniu i implementacji strategii organizacji istotną rolę zajmują właśnie strategie personalne. Niewątpliwie warunkują one efektywne wykorzystanie potencjału ludzkiego organizacji oraz możliwość osiągnięcia przewagi konkurencyjnej na rynku. Celem artykułu jest zaprezentowanie specyfiki zasobów ludzkich w NGOs oraz przedstawienie polityki personalnej na przykładzie organizacji pozarządowych z Polski południowo-wschodniej.

\section{SPECYFIKA KAPITALU LUDZKIEGO W ORGANIZACJACH POZARZĄDOWYCH}

Polskie stowarzyszenia i fundacje bazują przede wszystkim na pracy społecznej, na pracy członków danej organizacji i obywateli w formie wolontariatu. Dlatego też jednym z głównych czynników społeczno-kulturowych warunkujących istnienie i rozwój organizacji trzeciego sektora jest gotowość społeczeństwa do zaangażowania się w ich działania.

\footnotetext{
${ }^{1}$ Dr Agnieszka Zielińska, Katedra Marketingu, Wydział Zarządzania, Politechnika Rzeszowska.

${ }^{2}$ Dz.U. nr 96 z 29 maja 2003 roku, pozycja 873, art. 3 ust. 2.

3 J. Herbst, J. Przewłocka, Podstawowe fakty o organizacjach pozarzqdowych. Raport z badania 2010, Stowarzyszenie Klon/Jawor, Warszawa 2011, s. 10.
} 
Na podstawie raportu przygotowanego przez Eurofund około jedna piąta obywateli Unii Europejskiej uczestniczyła w wolontariacie. Największy odsetek osób podejmujących pracę jako wolontariusze odnotowano w Danii, Finlandii i Szwecji. Najmniej osób chętnych do bezinteresownej pomocy było w Bułgarii i Rumunii (10-15\% wolontariuszy) ${ }^{4}$. Polska uplasowała się na piątym miejscu od końca z wynikiem prawie $21 \%$ wolontariu$\mathrm{szy}^{5}$. Różnice te mogą wynikać z przyczyn politycznych oraz historycznych.

W Polsce w 2011 r. członkami ,jakichś organizacji, stowarzyszeń, partii, komitetów, rad, grup religijnych, związków lub kół" było 14,8\% respondentów: 11,6\% należało tylko do jednego stowarzyszenia, 2,2\% do dwóch, a 1\% do dwóch lub więcej. Natomiast 85,2\% nie należy do żadnej organizacji ${ }^{6}$.

Stowarzyszenia zrzeszają przeciętnie 35 członków (fundacje zgodnie z obowiązującym prawem nie mają członków). Niestety, jak wynika z deklaracji NGOs, średnio ponad jedna trzecia to członkowie ,wirtualni”. Nie uczestniczą w życiu organizacji, nie przychodzą na zebrania, nie opłacają składek członkowskich oraz praktycznie nie utrzymują kontaktów $\mathrm{z}$ organizacją ${ }^{7}$. W wypadku zarządu to w większości organizacji (ok. 64\%) liczba jego członków kształtuje się od trzech do pięciu osób. W niemal wszystkich NGOs (97\%) członkowie lub przedstawiciele władz regularnie pracują na rzecz organizacji, nie dostając za to wynagrodzenia. W około $50 \%$ organizacji ich praca społeczna daje w sumie co najmniej 42 godziny miesięcznie, w jednej szóstej przepracowują co najmniej 170 godzin, co równa się jednemu etatowi ${ }^{8}$.

W 2008 r. według danych z GUS trzeci sektor zatrudniał ok. 71 tysięcy pracowników. Analizując zatrudnienie płatnego personelu można stwierdzić, że blisko połowa polskich organizacji w 2010 r. korzystała z takiego wsparcia personalnego. Najpopularniejsze formy zatrudnienia w polskich NGOs to praca na część etatu w niepełnym wymiarze czasu pracy, na umowę zlecenie, wykonawstwo czy praca na cały etat ${ }^{9}$. $Z$ płatnym personelem na stałe współpracuje $24 \%$ organizacji z płatnymi pracownikami, a $20 \%$ korzysta z jednorazowych umów lub zleceń. Nowe miejsca pracy są tworzone dla potrzeb realizacji projektów. Natomiast czynnikiem zniechęcającym organizacje do zatrudniania pracowników na umowę o pracę jest brak ciąłości pozyskiwania środków finansowych ${ }^{10}$.

Brak płatnego personelu NGOs rekompensują zaangażowaniem członków danej organizacji i społeczeństwa w formie wolontariatu. Z wolontariatu zewnętrznego w $2010 \mathrm{r}$. korzystała połowa polskich NGOs. Wyniki te świadczą o wzroście zainteresowania wolontariatem w trzecim sektorze, ponieważ w 2008 r. jedynie 44\% organizacji zadeklaro-

\footnotetext{
4 Monitorowanie jakości życia $w$ Europie: udzial $w$ wolontariacie $i$ pracy nieodplatnej, http://www.eurofound.europa.eu/pubdocs/2011/021/p1/1/EF11021PL.pdf

${ }^{5}$ L.M. Salamon, S.W. Sokołowski, R. List, Global Civil Society. An Overview, The John Hopkins University, Baltimore 2003, s. 19.

${ }^{6}$ Diagnoza spoleczna 2011. Warunki i jakość życia Polaków. Raport, red. J. Czapiński, T. Panek, Rada Monitoringu Społecznego, Warszawa 2011, s. 278

http://www.diagnoza.com/pliki/raporty/Diagnoza_raport_2011.pdf.

${ }^{7}$ J. Herbst, J. Przewłocka, op. cit., s. 46-47.

${ }^{8}$ Jest praca w sektorze NGO, http://www.egospodarka.pl/72818,Jest-praca-w-sektorze-NGO,2,39,1.html.

${ }^{9}$ http://www.liderzy.pl/porady_ekspertow.php?167.

${ }^{10}$ M. Rymsza, Uwarunkowania i konsekwencje wzrostu zatrudnienia w trzecim sektorze, „Trzeci Sektor” 20052006/4, s. 11
} 
wało współpracę z wolontariuszami, a w 2006 było to zaledwie 40\%. Średnio w organizacji działa 10 wolontariuszy, z których połowa robi to często i systematycznie ${ }^{11}$.

Proces kierowania ludźmi w NGOs znacznie się różni od tego spotykanego w firmach z powodu odmiennej motywacji członków organizacji non-profit. W przeciwieństwie do świata biznesu, który skupia się na osiaganych zyskach, motorem działań dla uczestników organizacji pozarządowych jest służenie wyższym celom. Co więcej, motywacja w organizacjach pozarządowych powinna być oparta na: misji organizacji, mądrym przywództwie, wzajemnym zaufaniu, byciu u źródeł problemów, dwukierunkowej wrażliwości, dyscyplinie osobistej oraz pracy zespołowej ${ }^{12}$. Członków organizacji, pracowników czy wolontariuszy zatem motywuje do pracy idea społeczna, a czynnik ekonomiczny jest na dalszym miejscu. Wolontariusze angażują się $\mathrm{w}$ prace tych organizacji pozarządowych, które zaspokajają ich potrzeby i oczekiwania ${ }^{13}$.

$\mathrm{Na}$ podstawie badań przeprowadzonych przez Magdalenę Dudkiewicz najistotniejszymi determinantami angażowania się w prace NGOs były: zainteresowania, traumatyczne przeżycia, tradycje rodzinne, a także zewnętrzne okoliczności społeczne i ekonomiczne. Znaczna większość zdecydowała się na prace na rzecz organizacji pozarządowych z pobudek altruistycznych ${ }^{14}$.

\section{KIEROWANIE ZASOBAMI LUDZKIMI W ORGANIZACJACH POZARZĄ- DOWYCH Z POLSKI POLUDNIOWO-WSCHODNIEJ}

Zarządzanie zasobami ludzkimi jest to strategiczna, jednorodna i spójna metoda kierowania kapitałem ludzkim organizacji ${ }^{15}$. Dotyczy decyzji związanych z planami organizacyjnymi, stosunku zatrudnienia, rekrutacji, szkoleń pracowników, a także z zarządzaniem stosunkami $\mathrm{z}$ pracownikami oraz przez wynagrodzenia. W literaturze przedmiotu można znaleźć kilka klasyfikacji strategii personalnych ${ }^{16}$. Na potrzeby tego artykułu nawiązano do strategii ofensywnej i defensywną oraz modelu sita i kapitału ludzkiego ${ }^{17}$.

Warto podkreślić również za Krzysztofem Obłojem, że nie wystarczy zainwestować dostatecznie dużo w nowe technologie i maszyny, a wszystko się zmieni na lepsze. Kluczem do sukcesu są niematerialne zasoby organizacji. Bez odpowiedniego kapitału intelektualnego każda strategia i przewaga strategiczna jest jedynie chwilowa i niepewna ${ }^{18}$. Dlatego tak ważna jest odpowiednia polityka personalna w organizacjach pozarządowych.

\footnotetext{
${ }^{11}$ J. Herbst, J. Przewłocka, op. cit., s. 52-53.

${ }^{12}$ P.F. Drucker, Zarzqdzanie organizacja pozarzqdowq. Teoria i praktyka, Fundusz Współpracy, Warszawa 1995, s. 80

${ }^{13}$ M. Rymsza, op. cit., s. 11.

${ }^{14}$ M. Dudkiewicz, Postrzeganie polskiego sektora i jego otoczenia spolecznego przez personel organizacji pozarzqdowych, „Trzeci Sektor” 2006/5, s. 68.

${ }^{15}$ M. Armstrong, Zarzqdzanie Zasobami Ludzkimi - Strategia i działanie, Wolters Kluwer Business, Kraków 2011, s. 117

${ }^{16}$ Więcej zob. Zarzadzanie kadrami, red. T. Listwan, C.H. BECK, Warszawa 2002, s. 40-44; R. Jurkowski, Prawne i ekonomiczne aspekty zarzqdzania ludźmi w firmie, Dom Wydawniczy ABC, Warszawa 2002, s. 7175, Z. Janowska, Zarzadzanie zasobami ludzkimi, PWE, Warszawa 2002, s. 22-24.

${ }^{17}$ Więcej zob. Zarzqdzanie kadrami..., s. 40, A. Ichniowska, Human Resources Management in Polish Nongovernmental Organizations, [w:] Znalostni ekonomika - trendy rozvoje vzdelavani, vedy a praxe, 2007.

${ }^{18}$ K. Obłój, Strategia sukcesu firmy, PWE, Warszawa 1993, s. 92.
} 
Dokonano zatem analizy danych związanych ze strukturą społeczną organizacji ${ }^{19}$. Wśród badanych organizacji stwierdzono znaczną różnorodność w zakresie wielkości zarządów. Badania własne przeprowadzone wśród NGOs z terenu Polski południowo-wschodniej wskazały, że najczęściej w zarządzie organizacji znajdowało się 5-10 osób. Około 34\% organizacji miało do 5 członków zarządu. Powyżej 10 osób liczył zarząd nielicznych organizacji. Średnia osób w zarządzie wyniosła 7 osób. Wyższe wykształcenie miało średnio 4\% członków zarządu. Wykształcenie z zakresu zarządzania i ekonomii średnio miało 1,6\% osób. Natomiast w 2010 r. - jak wynika z badań ogólnopolskich - w większości organizacji (ok. 64\%) liczba jego członków zarządu kształtowała się 3-5 osób. Niektórzy autorzy - między innymi W.T. Gangl - wskazują, że liczba członków zarządu ma wpływ na efektywność zarządzania organizacjami ${ }^{20}$. Zbyt duża ilość osób w zarządzie może powodować ich mniejszą skuteczność $\mathrm{w}$ podejmowaniu decyzji, z powodu dłuższych dyskusji i braku zaangażowania poszczególnych członków, jak również ze względu na rozmycie odpowiedzialności za losy organizacji. Natomiast zaletą może być większa skuteczność w pozyskiwaniu środków finansowych od donatorów. Najskuteczniejszy sposób zarządzania organizacją zapewnia zarząd w którego skład wchodzi 10-15 osób ${ }^{21}$.

Płatny personel miało 51\% organizacji z terenu Polski południowo-wschodniej, a $41 \%$ nie zatrudniało pracowników. Brak płatnego personelu organizacje rekompensują zaangażowaniem członków danej organizacji i społeczeństwa w formie wolontariatu. Z przeprowadzonej analizy wynikało, że większość NGOs (78\%) korzystało z pracy wolontariuszy. Praca lub wolontariat $\mathrm{w}$ trzecim sektorze jest ciekawą alternatywą dla pracy w pozostałych dwóch sektorach, może to być bowiem cenny etap w karierze, ponieważ coraz częściej firmy szukają osób, które mają doświadczenie pracy w organizacji pozarządowej ${ }^{22}$.

Respondenci podczas rekrutacji pracowników największą uwagę zwracali na gotowość do zaangażowania w pracy oraz na wrażliwość kandydata na dane stanowisko. Natomiast niewielkie znaczenie miały gotowość do podejmowania ryzykownych decyzji, zdolności przywódcze czy staż pracy.

Ponadto analizując politykę kadrową można zauważyć, że organizacje pozarządowe z Polski południowo-wschodniej zwracały uwagę na dobrą atmosferę pracy oraz na możliwość samorealizacji pracowników NGOs. Daje się również odczuć przekonanie, że zwalnianie pracowników to ostateczność. Co więcej, jedynie $21 \%$ badanych całkowicie zgodziło się ze stwierdzeniem, że motywacją do pracy stanowi czynnik ekonomiczny. Tylko niewielki procent przedstawicieli organizacji uważał, że pracownicy powinni między sobą rywalizować.

Organizacje wskazały także, że szkolenia są ważnym aspektem zarządzania kapitałem ludzkim. Większość organizacji pozarządowych z Polski południowo-wschodniej (72\%) deklarowało, że ich pracownicy przechodzą przez wewnętrzne lub zewnętrzne szkolenie przygotowujące ich do pracy. W wypadku wolontariuszy jeszcze mniejszy odsetek orga-

\footnotetext{
${ }^{19}$ Badania własne przeprowadzono w organizacjach pozarządowych. Zakres przestrzenny badań obejmował Polskę południowo-wschodnią. Próba badawcza objęła 104 organizacje pozarządowe. Badanie przeprowadzono metodą ankiety bezpośredniej od maja 2007 do kwietnia $2008 \mathrm{r}$.

${ }^{20}$ W. T. Gangl, Creating and Management Effective Governance for Nonprofits and Foundations II, "Directionship" 24/9 (1998), s. 10-14, cyt. za: E. Bogacz-Wojtanowska, Zarzadzanie organizacjami pozarzqdowymi na przykładzie stowarzyszeń krakowskich, Wydawnictwo Uniwersytetu Jagiellońskiego, Kraków 2006.

${ }^{21}$ E. Bogacz-Wojtanowska, op. cit., s. 104.

${ }^{22}$ Jest praca $w$ sektorze NGO, http://www.egospodarka.pl/72818,Jest-praca-w-sektorze-NGO,2,39,1.html...
} 
nizacji zapewniało przeszkolenie. Organizacje pozarządowe zgłaszały zapotrzebowanie na różny zakres tematyczny szkoleń. Z badań własnych dotyczących potrzeb szkoleniowych wynikało, że największe zapotrzebowanie było na szkolenia z zakresu pozyskiwania środków finansowych. Aż 75\% respondentów wskazało, że taka tematyka szkolenia byłaby przydatna dla ich organizacji. Dużym zainteresowaniem cieszyły się również szkolenia specjalistyczne, które poruszałyby zagadnienia związane ze specyficzną dziedzina, w której działa organizacja (57\% badanych). Dla 38\% organizacji przydatne byłoby szkolenie z języków obcych. Najmniejszym zainteresowaniem cieszyły się szkolenia z zakresu stosowania nowoczesnych technologii czy budowania relacji z innymi sektorami. Tylko blisko $30 \%$ organizacji za przydatne uznało szkolenia z zakresu zarządzania ludźmi czy budowania wizerunku organizacji. Niepokojącym zjawiskiem jest to, że mimo spadku liczby wolontariuszy, czy też trudności w utrzymaniu dobrego personelu tylko nieliczne organizacje były zainteresowane zdobywaniem wiedzy z zarządzania kapitałem ludzkim, dotyczących między innymi budowania zespołu, prowadzenia zebrań czy przywództwa. Pozytywnym objawem było to, że tylko $2 \%$ badanych organizacji stwierdziło, że nie potrzebują szkoleń.

Ponadto, jak wynika z badań przeprowadzonych przez Stowarzyszenie Klon/Jawor w 2010 r. około połowa NGOs odczuwała problemy, czyli brak osób gotowych bezinteresownie działać na rzecz organizacji. Ponadto około $30 \%$ badanych miało trudności w utrzymaniu dobrego personelu i wolontariuszy. Dodatkowo dla $31 \%$ organizacji odczuwalną barierą było znużenie liderów organizacji oraz „wypalenie” się osób zaangażowanych $w$ ich prace ${ }^{23}$. Dlatego też pomocne w pokonaniu tych trudności mogłyby być szkolenia z zakresu zarządzania ludźmi i kreowania pozytywnego wizerunku organizacji. Dla osób kierujących organizacją pozarządową wskazane byłyby szkolenia z zakresu zarządzania personelem, projektami, finansami oraz zarządzania czasem ${ }^{24}$ Co więcej, jak proponuje Lisa W. Knowlton, wszystkich pracowników należy kształcić także z historii filantropii, kierowania i zarządzania organizacją ${ }^{25}$.

\section{PODSUMOWANIE}

W wyniku dużego zróżnicowana trzeciego sektora nie istnieje jeden standardowy wzór polityki personalnej w NGOs. Co więcej, Tomasz Szimanek uważa, że standaryzacja może przynieść negatywne skutki uboczne. Niewatpliwie zarządzanie personelem w polskich organizacjach pozarządowych jest trudne ze względu na brak wykwalifikowanej kadry. Polski trzeci sektor potrzebuje specjalistów z zakresu zarządzania, ponieważ przykłady organizacji pozarządowych ze Stanów Zjednoczonych pozwalają sądzić, że NGOs pod wpływem specjalistów z zakresu zarządzania oraz jednostek biznesu działają profesjonalniej, coraz skuteczniej realizując założenia strategiczne ${ }^{26}$. Dodatkowo cześć organizacji ma ograniczony budżet, dlatego też koszty tworzenia stanowisk pracy są dla nich zbyt wysokie ${ }^{27}$.

\footnotetext{
${ }^{23}$ J. Herbst, J. Przewłocka, op. cit., s. 148.

${ }^{24}$ S. Schaffer, Nonprofit Management Reconsidered, „Nonprofit World” 23/6 (2005), s. 24.

${ }^{25}$ L.W. Knowlton, Study Shows Gaps in Nonprofit Management - and Ways to Improve, „Nonprofit World”; $19 / 3$ (2001), s. 30.

${ }^{26}$ E. Bogacz-Wojtanowska, op. cit.

${ }^{27}$ Organizacje pozarzadowe $w$ spoleczeństwie obywatelskim - wyzwanie dla środowisk akademickich, red. A. Juros, Lubelski Ośrodek Samopomocy, Lublin 2002.
} 
W wypadku wolontariatu organizacje pozarządowe powinny pamiętać, że czynnikiem sprzyjającym rozwojowi profesjonalnego wolontariatu jest obecność płatnego personelu. Wynika to $\mathrm{z}$ odpowiedniego przygotowania i obsługi miejsc pracy wolontariuszy, udzielaniu merytorycznej pomocy oraz nadzorowaniu pracy wolontariuszy przez płatnych pracowników.

Podsumowując, na postawie badań własnych można stwierdzić, że organizacje pozarządowe przy doborze pracowników wykorzystywały model sita, a następnie zwerbowani już pracownicy byli traktowani według wytycznych modelu kapitału ludzkiego. Słuszność wykorzystania strategii defensywnej (modelu kapitału zarządzania ludzkiego) wynika ze specyfiki działania NGOs. Często wymagana jest praca zespołowa i współpraca $\mathrm{Z}$ wieloma podmiotami. Na podstawie badań własnych można również stwierdzić, że w procesie rekrutacji pracowników organizacji pozarządowych istotne sa kwalifikacje oraz dostosowanie kandydata do organizacji, jego wrażliwość społeczna i gotowość do poświęceń. Zarządzający NGOs doceniali budowanie przyjaznej atmosfery pracy opartej na współpracy, a nie na konkurencji między pracownikami. System motywacyjny odnosił się zarówno do aspektu finansowego, społecznego, jak i do psychologicznego. Najmocniej jednak akcentowana była możliwość samorealizacji.

\section{LITERATURA}

[1] M. Armstrong, Zarzadzanie Zasobami Ludzkimi - Strategia i działanie, Wolters Kluwer Business, Kraków 2011

[2] E. Bogacz-Wojtanowska, Zarzadzanie organizacjami pozarzqdowymi na przyktadzie stowarzyszeń krakowskich, Wydawnictwo Uniwersytetu Jagiellońskiego, Kraków 2006

[3] A. Czubała, A. Jonas, T. Smole, J. W. Wiktor, Marketing ustug, Oficyna Ekonomiczna, Kraków 2006

[4] Diagnoza spoteczna 2011. Warunki i jakość życia Polaków. Raport, red. J. Czapiński, T. Panek, Rada Monitoringu Społecznego, Warszawa 2011, http://www.diagnoza.com/pliki/raporty/Diagnoza_raport_2011.pdf

[5] Dlaczego warto rozważyć kariere w III sektorze, http://youngpro.pl/artykuly/1/sposob-nakariere/16/dlaczego-warto-rozwazyc-kariere-w-iii-sektorze

[6] P.F. Drucker, Zarzqdzanie organizacja pozarzqdowq. Teoria i praktyka, Fundusz Współpracy, Warszawa 1995

[7] M. Dudkiewicz, Postrzeganie polskiego sektora i jego otoczenia spotecznego przez personel organizacji pozarzadowych, ,Trzeci Sektor” 2006/5

[8] Dziennik Ustaw nr 96 z 29 maja 2003 roku, poz. 873, art. 3 ust. 2

[9] J. Dziwulski, Strategie zarzqdzania organizacjami non-profit, [w:] Organizacje pozarzqdowe w społeczeństwie obywatelskim - wyzwanie dla środowisk akademickich, red. A. Juros, Lubelski Ośrodek Samopomocy, Lublin 2002

[10] W.T. Gangl, Creating and Management Effective Governance for Nonprofits and Foundations II, „Directionship” 24/9 (1998)

[11] J. Herbst, J. Przewłocka, Podstawowe fakty o organizacjach pozarzadowych. Raport z badania 2010, Stowarzyszenie Klon/Jawor, Warszawa 2011

[12] http://www.liderzy.pl/porady_ekspertow.php?167

[13] Z. Janowska, Zarzqdzanie zasobami ludzkimi, PWE, Warszawa 2002

[14] Jest praca $w$ sektorze NGO, http://www.egospodarka.pl/72818,Jest-praca-w-sektorzeNGO,2,39,1.html

[15] R. Jurkowski, Prawne i ekonomiczne aspekty zarzqdzania ludźmi w firmie, Dom Wydawniczy ABC, Warszawa 2002 
[16] L.W. Knowlton, Study Shows Gaps in Nonprofit Management - and Ways to Improve, „Nonprofit World" 19/3 (2001)

[17] M. Kostera, Zarzqdzanie personelem, PWE, Warszawa 1999

[18] A. Kwiatkiewicz, Wzory zatrudnienia $w$ trzecim sektorze - perspektywa kadry zarzadzajacej. Wyniki badań empirycznych, „Trzeci Sektor” 2006/5

[19] M. Łojko, Strategie zarzqdzania zasobami ludzkimi w pomocy społecznej, [w:] B. Kromolicka, Praca socjalna w organizacjach pozarzadowych, Akapit, Torun 2005

[20] E. Masłyk-Musiał, Strategiczne zarzqdzanie zasobami ludzkimi, Oficyna Wydawnicza Politechniki Warszawskiej, Warszawa 2000

[21] Monitorowanie jakości życia $w$ Europie: udziat $w$ wolontariacie $i$ pracy nieodpłatnej, http://www.eurofound.europa.eu/pubdocs/2011/021/pl/1/EF11021PL.pdf

[22] Obłój K., Strategia sukcesu firmy, PWE, Warszawa 1993

[23] Organizacje pozarzqdowe w spoteczeństwie obywatelskim - wyzwanie dla środowisk akademickich, red. A. Juros, Lubelski Ośrodek Samopomocy, Lublin 2002

[24] M. Rymsza, Uwarunkowania i konsekwencje wzrostu zatrudnienia w trzecim sektorze, „Trzeci Sektor", 2005-2006/4

[25] L.M. Salamon, S.W. Sokołowski, R. List, Global Civil Society. An Overview, The John Hopkins University, Baltimore 2003

[26] S. Schaffer, Nonprofit Management Reconsidered, „Nonprofit World” 23/6 (2005)

[27] A. Szymkiewicz, J. Płaskoń, A. Tabaczyńska, Porzqdnie poza rzqdem, Akademia Rozwoju Filantropii w Polsce, Warszawa 1998

[28] J. Wyrwa, J. Jędrzejczak-Gas, Ekonomiczne uwarunkowania rozwoju organizacji non-profit, „Management” 8/2 (2004)

[29] Zarzqdzanie kadrami, red. T. Listwan, C.H. BECK, Warszawa 2002.

\section{HUMAN RESOURCES MANAGEMENT IN NGOS IN THE SOUTH-EAST POLAND}

The point of interest in the article is sector called also the third sector. The main goal of the article is to present the Human Resources Management in NGOs in the south-east Poland. The first part of the paper presents the unique characteristics of the work in NGOs. Next, it shows the HRM in NGOs in the south-east Poland.

DOI: $10.7862 /$ rz.2012.zim.12 